\title{
Van opvolgingsproblematiek naar een centrale rol voor de familie
}

\section{Veranderingen in de beeldvorming rond het familiebed rijf (2001 - 2005)}

Karen Verduyn

\begin{abstract}
'What do we talk about when we talk about the family firm?'
\end{abstract}
(Vrij naar: Gartner, 1990)

SAMENVATTING Dit artikel bespreekt een onderzoek naar (veranderingen in) de betekenis die wordt toegekend aan het familiebedrijf in de Nederlandse zakelijke media. De methode die wordt gehanteerd is de contentanalyse: we onderzochten de 'typische taal' (sleutelwoorden) in artikelen die gaan over familiebedrijven. Drie tijdsperioden zijn vergeleken: 2001, 2003 en 2005. Het overzicht van sleutelwoorden laat zien dat de sleutelwoordcategorie 'familie' tussen 2001 en 2005 aan betekenis heeft toegenomen. 'Opvolging' en 'leiderschap/bestuur' hebben aan betekenis afgenomen. Deze categorieën waren - binnen de onderzochte tijdsperiode(s) - het meest populair in 2001. 'Eigendom' was het meest populair in 2003.

RELEVANTIE VOOR DE PRAKTIJK Inzicht in de (verandering in de) betekenis die wordt toegekend aan het familiebedrijf in Nederland in de Nederlandse zakelijke media is relevant omdat het publiek van de zakelijke media wordt gevormd door de zakelijke gemeenschap. Deze laat zich (mede) informeren door de zakelijke media. De beeldvorming die (mede) als gevolg daarvan ontstaat, vormt een basis voor het nemen van beslissingen.

Dr. J.K. Verduyn is als universitair docent werkzaam bij de afdeling Management en Organisatiekunde van de Faculteit der Economische Wetenschappen en Bedrijfskunde van de Vrije Universiteit te Amsterdam.

\section{Inleiding}

Het familiebedrijf vormt een actueel onderwerp in veel Westerse landen, waaronder ook Nederland. Het is uiteraard geen nieuw fenomeen (het kennelijk oudste familiebedrijf in Nederland - Petit \& Fritsen - is reeds opgericht in 1660), maar de (media-) aandacht voor dit onderwerp is in de laatste jaren zeer sterk gegroeid. Dit artikel bespreekt een onderzoek naar (veranderingen in) de betekenis die wordt toegekend aan het familiebedrijf in de Nederlandse zakelijke media. Dit onderzoek is een vorm van tekstanalyse. Tekstanalyse is een manier om de betekenis van een tekst te achterhalen (o.a. Stubbs, 1996).

Hoewel er al veel aspecten van het familiebedrijf zijn onderzocht (zie bijvoorbeeld Sharma (2004) voor een overzicht), is er over de (maatschappelijke) betekenis die wordt toegekend aan het familiebedrijf nog niet veel bekend (een uitzondering wordt gevormd door Fletcher, 2002). Waarom onderzoek naar 'betekenis'? De betekenis die op enig moment aan een fenomeen wordt toegekend, zegt iets over hoe er over dat fenomeen wordt gedacht en gesproken, over de beeldvorming rond dat fenomeen. Hoe er over een fenomeen wordt gedacht en gesproken vormt weer de basis voor allerlei vormen van handelingen, waaronder het nemen van beslissingen: 'we kunnen menselijk gedrag niet begrijpen tenzij we kunnen bevatten welke betekenis daaraan ten grondslag ligt' (Tsoukas 2005, p. 98). 
De betekenis van een tekst hangt samen met tenminste drie facetten: 1) de tekst zelf, 2) wie de tekst heeft geproduceerd en 3) wie de tekst leest (Stubbs, 1996). Met de tekst zelf wordt bedoeld: de woorden die daadwerkelijk zijn opgeschreven. Dit onderzoek richt zich hoofdzakelijk op de tekst zelf en minder op wie de tekst geschreven heeft dan wel wie de tekst leest. Dit wordt overigens wel gezien als context voor de desbetreffende tekst(en); bij een analyse van een tekst hoort ook op zijn minst een beschrijving van wie de tekst heeft geproduceerd en wie de lezers zijn van de tekst (Stubbs, 1996). In het geval van mediateksten gaat het overigens meestal niet om een identificeerbare, individuele auteur of lezer, maar gaat het eerder om totale, sociale 'groepen'.

En waarom onderzoek naar de betekenis die wordt toegekend aan het familiebedrijf binnen de zakelijke media? De media spelen een belangrijke rol in het verspreiden van informatie, omdat ze zowel het verspreidingskanaal (het tijdschrift, de krant) als de inhoud van dat kanaal bepalen (Rindova et al., 2006). De media informeren een publiek over issues en gebeurtenissen (Chen en Meindl, 1991; Deephouse, 2000) en beïnvloeden zo stakeholders (Abrahamson en Fombrun, 1994; Deephouse, 2000; Lounsbury en Glynn, 2001; Pollock en Rindova, 2003).

Te weten hoe er in de zakelijke media over familiebedrijven wordt gesproken, is interessant en relevant om te weten omdat dit onderdeel uitmaakt van de zakelijke en maatschappelijke context waarbinnen familiebedrijven zich bewegen. Het publiek van de zakelijke media wordt gevormd door de zakelijke gemeenschap. Daaronder bevinden zich (ook) bankmanagers (die al dan niet besluiten een familiebedrijf te financieren en tegen welke condities), maar ook (potentiële en bestaande) klanten, concurrenten, potentiële en bestaande samenwerkingspartners, potentiële medewerkers en - niet in de laatste plaats - potentiële opvolgers. Zij laten zich informeren door de zakelijke media. De beeldvorming die (mede) als gevolg daarvan ontstaat, vormt weer een basis voor het nemen van beslissingen (Tsoukas, 2005). Ervan uitgaande dat een nadruk op bijvoorbeeld negatieve aspecten van familiebedrijven negatievere beslissingen tot gevolg zouden kunnen hebben, zou een veranderende (gunstigere?) discussie in de zakelijke media rond familiebedrijven bijvoorbeeld (mede) aanleiding kunnen zijn voor positievere beslissingen (en daarmee wellicht een positiever financieringsklimaat, meer klanten en een gunstigere arbeidsmarkt). Overigens strekt dit onderzoek zich niet zover uit dat ook daadwerkelijk de effecten van de veranderende discussie worden gemeten.
Omdat een beeld geen statisch gegeven is, wordt in dit artikel geen momentopname gepresenteerd, maar wordt ook gekeken naar eventuele verschuivingen in de betekenis die wordt toegekend aan het fenomeen familiebedrijf. Dit kan worden uitgelegd met behulp van het begrip 'taalspel'. Wittgenstein (1953) introduceerde dit begrip om aan te geven dat geen enkele term, geen enkel concept één vaste betekenis heeft. De betekenis van een fenomeen, een concept, is geen statisch gegeven; het is niet vast te leggen. Elk concept heeft meerdere betekenissen en de betekenissen die een concept kan krijgen bewegen en veranderen. Er zijn ontelbaar veel manieren om woorden te gebruiken en manieren om een fenomeen te beschrijven; we kunnen met woorden spelen. Een taalspel 'leeft'; volgens Wittgenstein is de betekenis van elk concept onderdeel van het leven zelf, is het 'een vorm van leven'.

Middels dit onderzoek willen we dan ook enerzijds onderzoeken welke woorden er op enig moment vanuit de zakelijke media worden gebruikt om het fenomeen familiebedrijf te duiden (de constellatie van betekenissen van het begrip familiebedrijf binnen die periode). Anderzijds willen we kijken hoe deze constellatie van betekenissen verandert, in beweging is. Daartoe kijken we naar drie verschillende tijdsperiodes: 2001, 2003 en 2005.

Na deze uiteenzetting van de leidende onderzoeksvraag van dit artikel, de daarin centraal staande concepten, de potentiële praktische relevantie van het onderzoek en een korte beschrijving van de opzet, bespreken we nu eerst het concept familiebedrijf vanuit een wetenschappelijke invalshoek. Vervolgens bespreken we de gekozen methode: contentanalyse. Aanvullend worden de resultaten besproken en bediscussieerd. Er wordt afgesloten met een conclusie.

\section{Het familiebedrijf}

'Een bedrijf is een familiebedrijf als het aan minstens twee van de volgende drie criteria voldoet: meer dan 50 procent van de eigendom is in handen van één familie; één familie heeft beslissende invloed op de bedrijfsstrategie of op opvolgingsbeslissingen; een meerderheid of ten minste twee leden van de ondernemingsleiding zijn afkomstig uit één familie' (Flören, 2002, p. 11). Uit deze definitie blijkt dat in ieder geval 'eigendom' en 'leiding' belangrijke aspecten zijn van familiebedrijven. Een zeer populair model om de verschillende aspecten van het familiebedrijf weer te geven is het 'driecirkelmodel': Morris et al. (1997) hebben het familiebedrijf als een 'totaal systeem' geconceptualiseerd, bestaande uit een aantal sub- 
systemen waaronder het bedrijf als entiteit, de familie als entiteit en de oprichter van het bedrijf als entiteit. Elk van deze subsystemen heeft een unieke (en potentieel met andere subsystemen conflicterende) identiteit en cultuur, en bevat ook weer eigen subsystemen. Om het familiebedrijf te begrijpen, moeten we volgens Morris et al. de interacties tussen de diverse subsystemen begrijpen.

Tagiuri en Davis (1992) hebben beargumenteerd dat een driecirkelmodel van het familiebedrijf bestaat uit familie, bedrijf en eigendom (zie ook figuur 1). Het driecirkelmodel van Tagiuri en Davis kan worden gezien als een uitbreiding van Morris et al.: degene die het bedrijf opricht is normaliter de eigenaar tot er een opvolging plaatsvindt. De bredere term 'eigendom' is dus passender vanaf het moment dat de tweede generatie zijn intrede heeft gedaan. Het model van Tagiuri en Davis betreft zodoende een grotere variatie aan familiebedrijven.

Het model helpt om een overzicht van kernconcepten te formuleren die samenhangen met het familiebedrijf:

- de mate van betrokkenheid van de familie en de mate van verbondenheid tussen familie en bedrijf (in andere woorden: de overlap tussen familie en bedrijf);

- opvolging en betrokkenheid van andere generaties;

- eigendom (aandelen, stemrecht) en het percentage aandelen dat in handen is van (leden van) de familie (het aandeel en de wijze van familie-eigendom);

- de (hoeveelheid) managementposities die worden bekleed door familieleden (leiderschap). Dit hangt samen met het bestuur (governance) van het familiebedrijf: familie-invloed brengt specifieke problemen met zich mee.

Deze kernconcepten vormen kort gezegd vier categorieën aan aspecten die samenhangen met het familiebedrijf: opvolging, leiderschap/bestuur, eigendom en familie. Deze laatste categorie verwijst naar de overlap tussen familie en bedrijf. De categorieën eigendom en opvolging hangen uiteraard samen. Hetzelfde geldt voor opvolging en leiderschap/bestuur; opvolging betekent doorgaans dat het eigendom in andere handen overgaat. Deze categorisering is dan ook geen strikte scheiding. Het vormt een manier om bij de bespreking van de resultaten van dit onderzoek (zie paragraaf 4) verschuivingen in aandachtspunten tussen periodes te belichten. Zorgvuldige categorisering (bijvoorbeeld op basis van wetenschappelijke literatuur) is belangrijk voor de gekozen onderzoeksmethode, namelijk contentanalyse (zie o.a. Schrøder, 2002). Deze onderzoeksmethode wordt uitgebreid besproken in de volgende paragraaf.

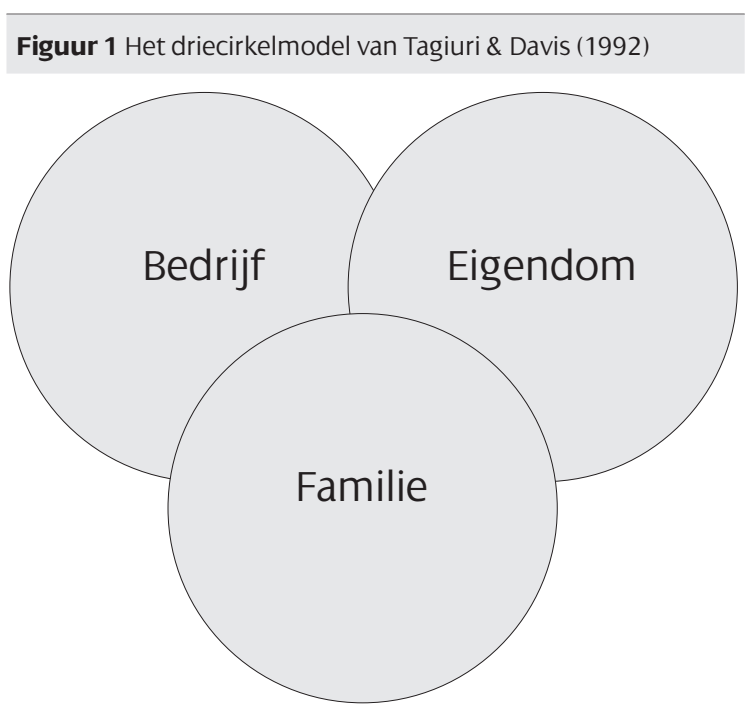

\section{Onderzoeksopzet}

Dit artikel bespreekt een onderzoek naar (veranderingen in) de betekenis die wordt toegekend aan het fenomeen familiebedrijf in de zakelijke media in Nederland. Deze betekenis is gemeten door middel van een contentanalyse van mediateksten: 'contentanalyse is een onderzoeksmethode die gebruik maakt van een aantal procedures om valide conclusies te kunnen trekken uit tekst' (Weber, 1990, p. 9).

Voor de contentanalyst vormen teksten (maar ook beelden en uitdrukkingen) de basis voor handelingen (zie ook paragraaf 1 ) en moeten ze ook als zodanig geïnterpreteerd en geanalyseerd worden (Krippendorff, 2004). Er zijn diverse benaderingen van contentanalyse. Liang en Wang (2004, p. 400) stellen derhalve dat deze systematische benadering met een aanzienlijke flexibiliteit kan worden toegepast. Sommige toepassingen zijn breder van aard, andere meer geconcentreerd op een specifieke kwestie.

Contentanalyse zoals we dat hebben toegepast in dit onderzoek is een manier om de betekenis van een fenomeen te achterhalen. Een misvatting rond contentanalyse is dat het zou blootleggen wat er eigenlijk bedoeld wordt met een tekst; een zekere dieperliggende boodschap (Krippendorff, 2004). Contentanalyse is geen methode om een 'essentiële boodschap' uit te filteren. Het aspect van contentanalyse waar wij ons in dit onderzoek op gericht hebben is de 'typische' taal die wordt gebruikt in een tekst.

De 'typische taal' maakt inzichtelijk wat een tekst karakteriseert. 'Typische taal' refereert naar termen die vaker (of juist: minder vaak) voorkomen in een tekst dan men zou verwachten op basis van het voorkomen van die termen in een algemeen verband (een 
voorbeeld betreft politieagenten die in de context van hun werk andere termen bezigen dan wanneer ze niet aan het werk zijn).

Er zijn drie tekstbestanden (bronteksten) geanalyseerd, een voor elke periode. Deze tekstbestanden zijn vergeleken met een referentiecorpus met behulp van de 'keywords-tool' van het collocatiesoftwareprogramma Wordsmith. 'Keywords' (sleutelwoorden) zijn in dit verband woorden die ongebruikelijk vaak (of minder vaak) voorkomen in vergelijking met een referentiecorpus. Als zodanig zijn de sleutelwoorden dan ook bijzonder nuttig om een tekst te karakteriseren (middels de 'typische taal' die deze bevat). De 'keywords-tool' van Wordsmith levert twee soorten informatie op:

- de frequentie van elk sleutelwoord in de brontekst(en);

- een vergelijking ervan met de frequentie in het referentiecorpus.

De sleutelwoorden in de bronteksten worden geordend naar de mate van 'key-ness' ${ }^{\text {' }}$ in andere woorden, de mate waarin ze een sleutelpositie hebben in de tekst. Een hoge 'key-ness' geeft aan dat het woord cruciaal is in het beschrijven van het verschil tussen het voorkomen van het sleutelwoord in het referentiecorpus en in de kleinere woordlijst. Een afwijkend sleutelwoord heeft een opmerkelijke frequentie in de kleinere woordlijst vergeleken met het referentiecorpus.

Het referentiecorpus voor dit onderzoek bestond uit alle artikelen die zijn gepubliceerd in het Algemeen Dagblad in 2004. Dit corpus is speciaal voor het onderzoek samengesteld, omdat er geen geschikt (Nederlandstalig) corpus voorhanden was. Het Algemeen Dagblad is gekozen omdat dit een algemeen publiek adresseert (in tegenstelling tot het specifiek zakelijke publiek uit de centrale onderzoeksvraag). Het totale aantal woorden in het referentiecorpus is 5.616.024.

De LexisNexis Academic database is gebruikt om de drie bronteksten samen te stellen. Deze database bevat artikelen uit onder meer FEM Business, Het Financieele Dagblad en de bedrijfseconomische secties van NRC Handelsblad, Het Parool, De Telegraaf, Trouw, en de Volkskrant. Het dominante publiek wordt gevormd door managers en ondernemers - de zakelijke gemeenschap.

Zoekwoorden die zijn gebruikt bij het selecteren van teksten zijn 'familiebedrijf' en 'familiebedrijven'.
Alleen artikelen langer dan 750 woorden zijn in de selectie opgenomen vanwege het minder beschrijvende, eerder anekdotische karakter van kortere teksten. Alle teksten zijn doorgelezen om er zeker van te zijn dat het artikel voldoende over familiebedrijven ging.

We hebben artikelen uit de eerste helft van 2001 en 2005 en artikelen van april tot en met september 2003 in de selectie opgenomen. De onderliggende reden is dat we zeker wilden zijn dat overeenkomsten tussen jaren niet toe te schrijven zouden zijn aan de gekozen periode. De 2001-selectie is uitgebreid met de maand augustus en de 2003-selectie met de maanden maart en oktober omdat de 2005-selectie veel meer woorden bleek te bevatten dan de andere twee. Tabel 1 laat het aantal woorden per periode en het totale aantal woorden zien.

Tabel 1 Aantal woorden per tekst per periode

\begin{tabular}{|l|l|}
\hline Jaar & Aantal woorden \\
\hline 2001 & 25,590 \\
\hline 2003 & 20,619 \\
\hline 2005 & 32,870 \\
\hline Totaal & $\mathbf{7 9 , 0 7 9}$ \\
\hline
\end{tabular}

In de nu volgende paragraaf - die de resultaten van het onderzoek presenteert en bespreekt -wordt ingegaan op het overzicht van de frequenties (zowel positief als negatief) van de sleutelwoorden per periode.

\section{Resultaten}

Zoals uitgelegd in de vorige paragraaf zijn sleutelwoorden bijzonder nuttig om een tekst te kunnen karakteriseren aan de hand van de 'typische taal' die deze bevat. Daarbij zijn we geïnteresseerd in zowel de positieve (woorden die veel vaker voorkomen dan zou worden verwacht op basis van het referentiecorpus) als de negatieve sleutelwoorden (woorden die veel minder vaak voorkomen dan zou worden verwacht op basis van het referentiecorpus). Tabel 2 geeft een overzicht van de tien meest ongebruikelijk frequent voorkomende, positieve en relevante ${ }^{2}$ sleutelwoorden per periode.

De sleutelwoorden in tabel 2 kunnen - zoals eerder aangegeven - dus allemaal ruwweg worden gecategoriseerd in de vier eerder gedefinieerde kernconcepten in het wetenschappelijk onderzoek naar familieondernemerschap: opvolging, eigendom, leiderschap/ 
Tabel 2 Overzicht van de tien meest ongebruikelijk frequent voorkomende, positieve, relevante sleutelwoorden per periode. Tussen haakjes: de 'key-ness'1.

\begin{tabular}{|c|l|l|l|}
\hline & 2001 & $\mathbf{2 0 0 3}$ & $\mathbf{2 0 0 5}$ \\
\hline $\mathbf{1 .}$ & Opvolging $[448,25]$ & Aandeelhouders $[426,88]$ & Familie $[513,24]$ \\
\hline $\mathbf{2 .}$ & Familiale $[268,76]$ & Opvolging $[278,83]$ & Familieforum $[378,61]$ \\
\hline $\mathbf{3 .}$ & Ondernemer $[257,61]$ & Familie $[207,73]$ & Aandeelhouder $[202,84]$ \\
\hline $\mathbf{4 .}$ & Externe $[242,44][$ adviseur/directeur] & Aandelen $[197,25]$ & Aandeelhouders [197,32] \\
\hline $\mathbf{5 .}$ & Familie $[192,30]$ & Stemrecht $[177,33]$ & Overdracht $[187,84]$ \\
\hline $\mathbf{6 .}$ & Bestuur $[174,37]$ & Aandeelhouder $[125,56]$ & Opvolging $[155,91]$ \\
\hline $\mathbf{7 .}$ & Governance $[139,75]$ & Bedrijfsopvolger $[121,91]$ & Generatie $[151,89]$ \\
\hline $\mathbf{8 .}$ & Overname $[138,80]$ & Directiecomité $[121,91]$ & Familiale $[143,25]$ \\
\hline $\mathbf{9 .}$ & Stichter $[131,47]$ & Opvolger $[110,34]$ & Familieleden $[125,43]$ \\
\hline $\mathbf{1 0 .}$ & Opvolger $[129,50]$ & Externe $[101,91][$ adviseur/directeur] & Kapitaalverschaffer $[102,32]$ \\
\hline
\end{tabular}

1 De 'key-ness' geeft dus aan in welke mate het voorkomen van het sleutelwoord in de brontekst verschilt van het voorkomen van datzelfde woord in het referentiecorpus. N.b.: de diverse waarden voor 'key-ness' kunnen alleen binnen een periode en niet tussen periodes vergeleken worden (129,50 (opvolger, 2001) kan niet worden vergeleken met 110,34 (opvolger, 2003)). Binnen een bepaalde periode kunnen de waarden voor 'key-ness' uiteraard wel worden vergeleken. In 2001 is opvolging (448,25) dus nog een stuk duidelijker een sleutelwoord dan familiale $(268,76)$, omdat het voorkomen van 'opvolging' in deze brontekst dus nog sterker afwijkt van het voorkomen ervan in het referentiecorpus dan 'familiale'.

bestuur en familie. Wanneer we bijvoorbeeld kijken naar 2001, dan kunnen zowel 'familiale' (2e plaats) als 'familie' (5e plaats) worden toegekend aan de familiecategorie. Als we langs deze lijnen doorredeneren, kunnen in deze zelfde periode opvolging (1e plaats), overname (8e plaats), stichter (9e plaats) en opvolger (10e plaats) worden toegekend aan de categorie 'opvolging. Om de relatieve betekenis van elke categorie tussen de drie periodes vast te kunnen stellen, hebben we naar twee zaken gekeken: de positie binnen een periode (de eerste keer dat een term wordt genoemd, van boven naar beneden geredeneerd) vergeleken met de positie binnen de andere periodes en het aantal termen binnen categorieën. Dit levert het volgende beeld op:

- Met betrekking tot de familiecategorie: in 2001 en 2003 staan familiale en familie respectievelijk op de tweede en derde plaats. In 2005 staat familie echter op de eerste plaats. Daarnaast komt er in 2001 twee keer een familiecategorie-gerelateerde term voor, in 2003 een keer en in 2005 vier keer. 'Familie' lijkt als aspect ergens tussen 2001 en 2005 belangrijker te zijn geworden. Ook zijn er in 2005 twee nieuwe termen: familieforum en familieleden.

- Met betrekking tot de eigendomcategorie: het eigendomsaspect (aandeelhouders) staat op de eerste plaats in 2003. Gerelateerde termen komen in 2003 een keer vaker voor dan in 2005. In 2003: aandeelhouders, aandelen, stemrecht en aandeelhouder en in 2005: aandeelhouder, aandeelhouders en overdracht. Hoewel in 2001 de term opvolging boven in de lijst staat komt er geen direct aan het eigendomsaspect gerelateerde term voor.

- Met betrekking tot de categorie opvolging: opvolging staat dus bovenaan de 2001-lijst, zakt naar een tweede plaats in 2003 en bekleedt slechts een zesde plaats in 2005. Vier aan de categorie opvolging gerelateerde termen komen voor in 2001 (opvolging, overname, stichter en opvolger), drie in 2003 (opvolging, bedrijfsopvolging en opvolger) en drie in 2005 (overdracht, overname en generatie). Kennelijk modieus in 2001, zakt het belang van opvolging als aspect van familieondernemerschap iets af richting 2003 en 2005.

- De categorie leiderschap/bestuur gaat - binnen het bestek van dit artikel - over de manier waarop het bedrijf wordt bestuurd en niet hoe, wanneer en of leiderschap overgaat naar een andere generatie of anderszins. In 2001 zien we vier verwijzingen naar dit onderwerp (externe [adviseur/directeur], ondernemer, bestuur en governance). In 2003 twee: stemrecht en directiecomité, en in 2005 slechts één: familieforum. De media-interesse in leiderschap/bestuur van familiebedrijven lijkt dus - binnen het bestek van de gekozen periodes - het hoogst in 2001, en wordt langzaam minder in 2003 en 2005.

De negatieve sleutelwoorden in de kleinere woordenlijsten - dat wil zeggen de termen die veel minder vaak voorkomen dan kan worden verwacht - zijn net zo interessant als de woorden die veel vaker voorkomen dan men zou verwachten op basis van het referentiecorpus. De negatieve sleutelwoorden zijn: tijd, aan, en euro (2001); ben, haar, mijn, te, hebben, nog, tegen, hij, was en ik (2003); week, haar, tegen (2005). Het is opvallend dat 'geld' in relatie tot familiebedrijven kennelijk minder interessant was dan in het algemeen, maatschappelijke debat. Immers, de euro werd in 2002 geïntroduceerd. 


\section{Discussie}

In dit artikel hebben we laten zien hoe de betekenis die vanuit de zakelijke media in Nederland aan het fenomeen familiebedrijf wordt toegekend in beweging is. Het overzicht van sleutelwoorden liet zien dat de sleutelwoordcategorie 'familie' aan betekenis heeft toegenomen tussen 2001 en 2005. 'Opvolging' en 'leiderschap/bestuur' hebben aan betekenis afgenomen. Deze categorieën waren - binnen de onderzochte tijdsperiode(s) - het meest populair in 2001. 'Eigendom' was het meest populair in 2003. Met andere woorden: de betekenis verandert, ofwel de aandacht verschuift. De vraag is nu: waardoor zou dit kunnen komen en wat zouden implicaties kunnen zijn?

Welke ontwikkelingen zouden ten grondslag kunnen liggen aan de verschuivingen? Een voor de hand liggende en vaak genoemde (zie o.a. Flören en Zwartendijk, 2003) oorzaak voor de stijging van aandacht voor het familiebedrijf in algemene zin is het feit dat veel oprichters van familiebedrijven 'producten' zijn van de babyboomgeneratie (1945 1955). De eerste oprichters uit deze generatie kwamen vanaf begin 2000 zo ongeveer op de leeftijd waarop men normaliter het arbeidzame leven afbouwt. Maar waarom dan een verschuiving van een nadruk op 'opvolging' gerelateerd aan 'leiderschap/bestuur' (2001) naar een nadruk op het eigendomsaspect in 2003 ? Een mogelijke verklaring zou kunnen worden gevonden in het feit dat wellicht binnen de opvolgingsoverwegingen rond familiebedrijven op de eerste plaats het aspect van opvolging in de leiding zich voordoet en er pas daarna wordt gekeken naar opvolging in het eigendom (volgens Sman en Thomassen (1994) zijn dit twee separate processen). Als we kijken naar wat er in meer algemeen, maatschappelijk opzicht speelde binnen en tussen deze tijdsperiodes valt op dat ontwikkelingen in deze periode ertoe hebben geleid dat op 10 maart 2003 de commissie Tabaksblat is geïnstalleerd. Hoewel men misschien op het eerste gezicht zou kunnen concluderen dat er dan juist in 2003 een toegenomen belangstelling zou bestaan voor de categorie leiderschap/ bestuur (en niet zozeer, zoals uit de data blijkt, voor de categorie eigendom), zijn er twee redenen waarom dit misschien niet direct op deze manier uit de data blijkt:

- In de eerste plaats is het uiteraard zo dat juist de ontwikkelingen voorafgaand aan het in het leven roepen van zo'n commissie van doorslaggevende betekenis zijn om zo'n commissie te installeren; leiderschap/bestuur was in 2001 ook in bredere zin al een issue (bijvoorbeeld: de teloorgang van Lernout \& Hauspie).

- In de tweede plaats is het hier belangrijk te kijken naar de inhoud van de opgegeven categorieën: 'eigendom' in 2003 refereert naar de sleutelwoorden 'aandeelhouders', 'aandelen', 'stemrecht' en 'aandeelhouder'. Aandeelhouders en aandelen zijn uiteraard juist nadrukkelijk punten van aandacht in (de mediaaandacht rond) de Corporate Governance Code van de commissie Tabaksblat.

De (media-)aandacht leidend tot en rond de commissie Tabaksblat kan dus goed een verklarende ontwikkeling zijn voor de media-interesse in het leiderschaps-/governance en eigendomsaspect van familiebedrijven (maar niet zozeer voor de verschuiving van de aandacht van het leiderschaps-/bestuursaspect naar het eigendomsaspect).

Een mogelijke verklaring voor de verschuiving van de media-aandacht van het opvolgingsaspect (2001) naar het meer familiale (2005) zou kunnen worden gevonden in een breder waar te nemen verschuiving van een nadruk op het problematische (en: 'oubollige') van familiebedrijven naar meer aandacht voor het succes ervan (zie ook Miller en Le Breton Miller, 2006; Burggraaf en Flören, 2006). Meer specifiek: 'opvolging' wordt vaak gezien als een specifiek probleem dat samenhangt met het familiebedrijf (o.a. Handler, 1994; Ibrahim et al., 2001; Flören, 2002). Als 'opvolging' op enig moment een populair thema is in de verslaglegging rond het familiebedrijf zou dit erop kunnen duiden dat juist het problematische aspect van het familiebedrijf de meeste aandacht krijgt, hetgeen op basis van de besproken resultaten dan dus binnen het bestek van de gekozen tijdsperiode in 2001 is geweest. De verschuiving van aandacht van het opvolgingsaspect naar de familiecategorie kan betekenen dat het accent is verplaatst naar de kern van wat het familiebedrijf zo bijzonder maakt, namelijk die overlapping tussen het bedrijf en de familie. Dat samen met het gegeven dat er in 2005 een nieuwe term, namelijk 'familieforum', de intrede heeft gedaan, zou kunnen impliceren dat behalve meer aandacht voor het bijzondere, er ook meer aandacht aan het ontstaan is voor de mogelijkheden, de kansen voor het familiebedrijf. Overigens zou dit kunnen worden geverifieerd door hetzelfde onderzoek nog een keer te doen, maar nu 2007 in het onderzoek te betrekken (en verder).

Naast deze mogelijke verklaring zou de verschuiving van aandacht voor het opvolgings- via het eigendomsnaar het familieaspect wellicht ook nog kunnen 
duiden op een patroon langs de lijnen van het driecirkelmodel van Tagiuiri en Davis (1992), namelijk dat de aandacht verschuift van 'bedrijf', naar 'eigendom', naar 'familie'. Ook dit zou kunnen worden geverifieerd door een langere tijdsperiode te onderzoeken, maar ook door meer (culturele) contexten te betrekken.

En wat betekent dit nu in termen van wat we in de introductie hebben beargumenteerd, namelijk dat te weten wat de beeldvorming is rond familiebedrijven en hoe deze beeldvorming verandert, een basis vormt voor het nemen van beslissingen (Tsoukas, 2005)? Zoals gezegd zou een nadruk op 'negatieve' aspecten van familiebedrijven negatievere beslissingen tot gevolg kunnen hebben en zou een veranderende (gunstigere) discussie rond familiebedrijven (mede) aanleiding kunnen zijn voor positievere beslissingen. Dit onderzoek gaat echter niet zover dat ook daadwerkelijk de effecten van de veranderende discussie worden gemeten; in dit onderzoek is gekeken naar de betekenis van de teksten zelf. Zowel het aspect van 'wie heeft de tekst geschreven' als 'hoe is de tekst ontvangen' zijn als context beschouwd.

Een laatste punt van discussie betreft een culturele kwestie: het onderzoek is beperkt tot de Nederlandse samenleving. Het betrekken van tenminste een aanvullende context zou de mogelijkheid hebben gecreeerd om vergelijkingen te trekken: zijn de veranderingen in aandachtspunten typisch voor de Nederlandse context of meer universeel? Is het 'normaal' dat de media-interesse rond familiebedrijven zich ontwikkelt van meer gericht op de opvolgingsmaterie naar meer gericht op het familieaspect (zie ook de hierboven genoemde suggestie rond het driecirkelmodel)? Zijn er misschien fasen te herkennen in de media-aandacht rond familiebedrijven? Deze en andere vragen kunnen worden beantwoord als er naar meerdere landen wordt gekeken.

\section{Conclusie}

De centrale onderzoeksvraag van dit artikel is: wat is de betekenis die vanuit de zakelijke media in Nederland wordt toegekend aan het fenomeen familiebedrijf en (hoe) verandert deze? We hebben kunnen constateren dat er inderdaad sprake is van beweging tussen 2001 en 2005. De sleutelwoordcategorie 'familie' heeft aan betekenis toegenomen tussen 2001 en 2005, en 'opvolging' en 'leiderschap/bestuur' binnen dit tijdsbestek - hebben aan betekenis afgenomen; deze categorieën waren - binnen de onder- zochte tijdsperiode(s) - het meest populair in 2001. 'Eigendom' was het meest populair in 2003. Dit zou kunnen impliceren dat de aandacht is verschoven van de opvolgingsproblematiek naar het bijzondere van het familiebedrijf, maar ook dat de aandacht is verschoven van het formele naar het meer informele aspect van het familiebedrijf.

Breed geformuleerd is dit onderzoek een bijdrage aan het begrijpen van familieondernemerschap in zijn (maatschappelijke) context. Inzicht in de betekenis die vanuit de zakelijke media wordt toegekend aan het familiebedrijf is interessant en relevant, omdat dit onderdeel uitmaakt van de zakelijke en maatschappelijke context waarbinnen familiebedrijven zich bewegen.

Er zijn suggesties voor vervolgonderzoek gedaan, te weten: een tijdsperiode te kiezen die verder doorgaat dan 2005, om meerdere culturele contexten te betrekken en niet alleen te kijken naar het beeld vanuit de media, maar ook bij bijvoorbeeld financiers, (potentiële) partners en (potentiële) medewerkers. Op die manier zou kunnen worden onderzocht of er sprake is van (unieke) patronen, maar ook wat daadwerkelijk effecten zijn van de veranderingen in beeldvorming.

\section{Literatuur}

Abrahamson, E. en C.J. Fombrun (1994), Macrocultures: determinants and consequences, Academy of Management Review, vol. 19, pp. 728-755.

Burggraaf, W. en R. Flören (2006), Ondernemers, familiebedrijven en de waarde van en voor de regio, Holland Management Review, vol. 107, pp. 42-47.

Chen, C.C. en J.R. Meindl (1991), The construction of leadership images in the popular press: the case of Donald Burr and People Express, Administrative Science Quarterly, vol. 36, pp. 521-551.

Davis, J. (1982), The influence of life stage on father-son work relationships in family companies, Harvard University.

Deephouse, D. (2000), Media reputation as a strategic resource: an integration of mass communication and resource based theories, Journal of Management, vol. 26, pp. 1091-1112.

Fletcher, D. (2002), Understanding the small family business, London: Routledge.

Flören, R. (2002), Cijfers en feiten van het familiebedrijf. 10 jaar onderzoek onder familiebedrijven, BDO Accountants \& Adviseurs.

Flören, R. en G. Zwartendijk (2003), Star en toch flexibel, Economisch Statistische Berichten, vol. 88, p. 20-21.

Gartner, W. B. (1990), What are we talking about when we talk about entrepreneurship? Journal of Business Venturing, vol. 5, pp. 15-28.

Hallam, J. (2002), Vocation to profession. Changing images of nursing in Britain, Journal of Organizational Change Management, vol. 15, pp. 35-47. 
Hamilton, E. (2006), Whose story is it anyway? Narrative accounts of the role of women in founding and establishing family businesses, International Small Business Journal, vol. 24, pp. 253-271.

Handler, W.C. (1994), Succession in family business: a review of the research, Family Business Review, vol. 7, pp. 133-157.

Ibrahim, A.B., K. Soufani en J. Lam (2001), A study of succession in a family firm, Family Business Review, vol. 14, pp. 245-258.

Jensen, K.B. (ed.) (2002), A handbook of media and communication research, London: Routledge.

Kellermanns, F.W. en K.A. Eddleston (2004), Feuding families: When conflict does a family firm good, Entrepreneurship Theory and Practice, vol. 28, no. 3, March, pp. 209-228.

Krippendorff, K. (2003), Content analysis: an introduction to its methodology, Thousand Oaks, CA: Sage.

Levinson, H. (1971), Conflicts that plague family business, Harvard Business Review, vol. 47, pp. 90-98.

Litz, R.A. en R.F. Kleysen (2001), Your old men shall dream dreams, your young men shall see visions: Toward a theory of family firm innovation with help from the Brubeck family. Family Business Review, vol. 14, pp. 335-351.

Lounsbury, M. en M.A. Glynn (2001), Cultural entrepreneurship: stories, legitimacy, and the acquisition of resources, Strategic Management Journal, vol. 22, pp. 545-564.

Miller, D. en I. Le Breton-Miller (2006), Goed en minder goed presterende familiebedrijven - lessen voor managers, Holland Management Review, vol. 108, pp. 8-21.

Morris, M.H., R.O. Williams, J.A. Allen, en R.A. Avila (1997), Correlates of success in family business transitions, Journal of Business Venturing, vol. 12, pp. 385-401.

Pollock, T.G. en V.P. Rindova (2003), Media legitimation effects in the market for initial public offerings, Academy of Management Journal, vol. 46, pp. 631-642.

Rindova, V.P., T.G. Pollock en M.L.A. Hayward (2006), Celebrity firms: the social construction of market popularity, Academy of Management Review, vol. 31, pp. 50-71.

Schoenberger, E. (2001), Corporate autobiographies: the narrative strategies of corporate strategists, Journal of Economic Geography, vol. 1, pp. 277-298.

Schrøder, K.C. (2002), Discourses of fact, in: K.B. Jensen (ed.), A handbook of media and communication research, London: Routledge.

Sharma, P. (2004), An overview of the field of family business studies: Current status and directions for the future, Family Business Review, vol. 17, pp. 1-36.

Sman, R. en A.J. Thomassen (red.) (1994), Uw onderneming in andere handen. Bedrijfsopvolging in theorie en praktijk, Den Haag: Delwel Uitgeverij.

Stubbs, M. (1996), Text and corpus analysis, Oxford: Blackwell.

Tagiuri, R. en J.A. Davis (1992), On the goals of successful family companies, Family Business Review, vol. 5, pp. 43-62.

Tsoukas, H. (2005), Afterword: why language matters in the analysis of organizational change, Journal of Organizational Change Management, vol. 18 , pp. 96-104.

Vera, C.F. en M.A. Dean (2005), An examination of the challenges daughters face in family business succession, Family Business Review, vol. 18, pp. 321-346

Ward, J.L. (1997), Growing the family business: Special challenges and best practices, Family Business Review, vol. 10, pp. 323-336. Weber, R.P. (1985), Basic content analysis, London: Sage. Wittgenstein, L. (1953). Philosophical investigations, Oxford: Blackwell.

\section{Noten}

1 De 'key-ness' geeft aan in welke mate het voorkomen van het sleutelwoord in de brontekst verschilt van het voorkomen van datzelfde woord in het referentiecorpus. De key-ness is een kruistabulatie van 1) de frequentie van het woord in de kleinere woordlijst, 2) het aantal woorden in de kleinere woordlijst, 3) de frequentie van het woord in het referentiecorpus en 4 ) het aantal woorden in het referentiecorpus.

2 'Relevant' betekent dat het betreffende woord verband houdt met het concept familieondernemerschap. De sleutelwoordenoutputlijst bevat ook tekens (zoals '\#') en veelgebruikte woorden zoals 'de', 'het', 'van'. Deze zijn niet opgenomen in de lijst met de tien meest ongebruikelijk frequent voorkomende relevante sleutelwoorden. Andere voorbeelden van woorden die niet in dit overzicht zijn opgenomen zijn namen van personen (Morskieft, Slippens, Wurth etc.) en bedrijven (Hooghoudt, Boskalis, Hagemeyer etc.) en woorden zoals 'koffie'. 